\title{
I mpact of photoperiod on circadian trehalose and trehalase rhythms in the digestive system of silkworm, Bombyx mori
}

\author{
E. B huvaneswari and S. Sivaprasad* \\ Department of Zoology, Smt. N.P.S. Government College for Women, Chittoor - 517002 (AP), INDIA. \\ *Corresponding author. E-mail: sivaprasadzoology@yahoo.co.in \\ Received:N ovember 8, 2012; Revised received:F ebruary 10, 2013; Accepted:M arch 5, 2013
}

Abstract: Circadian trehalose and trehalase rhythms were studied in the digestive system of Bombyx mori under $12 \mathrm{hr} \mathrm{light-dark} \mathrm{cycle} \mathrm{(LD),} \mathrm{continuous} \mathrm{light} \mathrm{(LL)} \mathrm{and} \mathrm{continuous} \mathrm{dark} \mathrm{(DD).} \mathrm{The} \mathrm{rhythmic} \mathrm{changes} \mathrm{were} \mathrm{interpreted}$ as synthetic cycles in gut wall and release cycles in gut lumen. The trehalose rhythm of gut wall comprised 8 trehalose synthetic cycles (TS cycles) under LD and LL and 7 under DD. The $24 \mathrm{hr}$ trehalose rhythm of LD and LL was clock shifted to $27.2 \mathrm{hr}$ under DD. The trehalose rhythm included 4 TR cycles under LD, 5 under LL and DD in the gut lumen and the $24 \mathrm{hr}$ rhythm of LD was clock shifted to $19.2 \mathrm{hr}$ under LL and DD. In the gut wall trehalase rhythm maintained 8 trehalase enzyme synthetic cycles (TES cycles) under LD, $10 \mathrm{LL}$ and 7 under DD and the $24 \mathrm{hr}$ rhythm of LD was clock shifted to $19.2 \mathrm{hr}$ under LL and $27.2 \mathrm{hr}$ under DD. In the gut lumen it included 4 TER cycles under LD and DD, 5 under LL and its 24-hr rhythm was advanced to $19.2 \mathrm{hr}$. Further analysis of data showed that LD favours trehalose synthesis, while LL and DD favour trehalase synthesis.

Keywords: Bombyx mori, Circadian trehalose rhythm, Circadian trehalase rhythm, Digestive system, Photoperiod

\section{INTRODUCTION}

Trehalose is the principal insect sugar that accounts for $23 \%$ of the total carbohydrate content of the body. It is a disaccharide comprising two glucose units joined by glycosidic linkages and is synthesized in the presence of trehalose phosphate synthase (Thompson, 2003). Principally, trehalose is synthesized and stored in the fat body and to a lesser extent in the gut wall cells and circulates in the haemolymph (Kanamori, 2010). Trehalose has been implicated in a multitude of functions in the insect body. It serves as energy source for metabolism, stabilizes protein and cell membrane structures against ill effects of high temperature and oxygen radicals as a cryoprotectant and regulates feeding mechanism as a signaling molecule (Nath, 2000; Banaroudji et al., 2001; Goto et al., 2001; Elbein et al., 2003; Thompson, 2003; Khani et al., 2007; Bolat, 2008; Han et al., 2008; Tang et al., 2008; Behroozi, 2010).

Trehalase is a metabolically active enzyme that hydrolyses trehalose to glucose and it is widely distributed in the tissues of Bombyx mori and other insects (Saito, 1960; Egorova and Khomidov, 1991). The activity levels of this enzyme facilitate homeostatic control of haemolymph trehalose levels in the silkworm (Yanagawa, 1979). Trehalase occurs in two inter convertible forms; a membrane bound trehalase-I (M.W: $73 \mathrm{KDa}, \mathrm{pH}$ 6.5) and a freely soluble, trehalase-II (M.W: $140 \mathrm{KDa}, \mathrm{pH}: 5.5)$ in the digestive system of insects and the later has a predominant role in metamorphosis
(Sumida and Yamashita, 1977; Huang et al., 2006). These two trehalases have been extensively studied with reference to their purification, properties, metabolism, cellular localization and homeostatic regulation (Saito, 1960; Nijhout, 1994; Terra and Ferreira, 2005; Becker et al., 1996; Oda et al., 2000; Thompson, 2003). In the silkworm tissues, the levels of trehalose and trehalase vary as function of the ongoing homeostatic mechanisms under the influence of hyper and hypo trehalosemic factors (Sutherland, 1972; Orchard et al., 1993; Roeder, 1999; Iwami, 2000; Leevers, 2001; Rulifson et al., 2002). It is likely that their levels could be altered in a circadian fashion under the control of peripheral circadian clocks. The available data on circadian clock mechanism in D rosophila and B. mori suggests that the physiological and biochemical processes are modulated by endogenous circadian oscillators under the influence of light and dark signals (Naidoo et al., 1999; Giebultowicz, 2001; Shimizu et al., 2001; Froy et al., 2003; Hall, 2003; Sharma, 2003; Sehadova et al., 2004; Iwai et al., 2006; Peschel et al., 2009). This has been demonstrated in our previous reports with reference to some biochemical constituents (Sailaja and Sivaprasad, 2010, a, b., Sailaja and Sivaprasad, 2011; Sailaja et al., 2011; Sivaprasad and Sailaja, 2011; Bhuvaneswari and Sivaprasad, 2012). However, no effort has since been made to study the impact of photoperiod on the circadian trehalose and trehalase rhythms in the digestive system of B. mori. The present study concentrates on this aspect. 


\section{MATERIALS AND METHODS}

The Pure Mysore x CSR hybrid variety of the Silkworm B. mori, reared under standard environmental conditions of $28^{\circ} \mathrm{C}, 85 \%$ relative humidity (Krishnaswami, 1986), was taken as the test species for the present study. After hatching, the worms were feed with $\mathrm{M}_{5}$ variety of mulberry leaves, five times a day at $6 \mathrm{AM}, 10 \mathrm{AM}, 2 \mathrm{PM}$, $6 \mathrm{PM}$ and $10 \mathrm{PM}$, under normal $12 \mathrm{hr}$ light and $12 \mathrm{hr}$ dark conditions. After third moult, the larvae were divided into three batches and reared separately under three different photoperiodic conditions viz., $12 \mathrm{hr}$ light and $12 \mathrm{hr}$ dark cycle (LD), continuous light (LL) and continuous dark (DD), but fed uniformly five times a day as usual. Circadian rhythmicity in the levels trehalose and trehalase activity in the two compartments of digestive system (gut wall and gut lumen) of silkworm was analyzed for a period of $25 \mathrm{hr}$ spanning in between day 5 and day 6 of fifth instar development. The gut wall tissue was isolated every hour by mid-dorsally dissecting the silkworm larvae in ice cold silkworm Ringer (Yamaoka et al., 1971) starting from 6 AM on day 5 through 6 AM on day 6 (i.e. for $25 \mathrm{hr}$ ). At the same time the gut content was extracted through a hypodermic syringe by inserting it into the lumen of the gut. The gut content, so collected was kept in a test tube under ice cold conditions till the mulberry leaf pieces were settled at the bottom and later the supernatant was decanted and used for the biochemical assay.

Hour- to- hour changes in trehalose of the gut wall and gut content were estimated by the method of Roe (1955) in 2\% homogenate of the gut wall tissue and 1:19 diluted gut content in ice-cold distilled water, using Anthrone reagent. The trehalose levels computed by using standard glucose were expressed as $\mathrm{mg}$ glucose/g wet weight of tissue or $1 \mathrm{ml}$ of gut content. Likewise, hour to hour changes in the trehalase activity was estimated by the method of Dahlman (1971) in 5\% homogenate of the gut wall and 1: 9 diluted digestive juice in ice cold phosphate buffer using DNS (Dinitro-salisylic acid) reagent. The enzyme activity was computed using glucose as standard and expressed in $\mu$ moles of glucose/ $\mathrm{mg}$ trehalose/ hour. The whole experiment lasted for two consecutive days encompassing 12:12 hr light and dark cycle (LD) for the first batch, continuous light (LL) for the second batch and continuous dark (DD) for the third batch. The first batch of the larva reared under LD was treated as the control while those reared under LL and DD were treated as the experimental samples.

\section{RESULTS}

The circadian trehalose and trehalase rhythms of the gut wall and gut content under three photoperiodic conditions LD, LL and DD were projected as phase response curves (PRCs) and presented in Figs. 1 to 4. The PRCs were analyzed in terms the number of peaks (elevated points) and troughs (low points) and intervals between peaks and troughs and the relevant details are shown in Tables 1 to 6 .

Circadian trehalose rhythm

Gut wall: Under LD, the trehalose rhythm of the gut wall showed 8 peaks and 8 troughs during the $24 \mathrm{hr}$ free running period of the rhythm (Fig.1A). The first peak occurred at $07 \mathrm{hr}$ with trehalose value of $109 \mathrm{mg} / \mathrm{g}$ wet wt. of tissue. Subsequent peaks occurred at $09 \mathrm{hr}(\sim 95$ $\mathrm{mg}), 12-13 \mathrm{hr}(\sim 88 \mathrm{mg}), 15 \mathrm{hr}(\sim 66 \mathrm{mg}), 19 \mathrm{hr}(\sim 75 \mathrm{mg})$ and next day at $01 \mathrm{hr}(\sim 122 \mathrm{mg}), 03 \mathrm{hr}(\sim 88 \mathrm{mg})$ and $06 \mathrm{hr}$ $(\sim 56 \mathrm{mg})$. Troughs occurred at $06 \mathrm{hr}(\sim 67 \mathrm{mg}), 08 \mathrm{hr}(\sim 53$ $\mathrm{mg}), 10 \mathrm{hr}(\sim 45 \mathrm{mg}), 14 \mathrm{hr}(\sim 34 \mathrm{mg}), 17 \mathrm{hr}(\sim 32 \mathrm{mg}), 20 \mathrm{hr}$ $(\sim 35 \mathrm{mg})$ and next day at $02 \mathrm{hr}(\sim 73 \mathrm{mg})$ and $04-05 \mathrm{hr}$ $(\sim 36 \mathrm{mg})$. Under LL, the trehalose rhythm showed 8 peaks and 7 troughs during the $24 \mathrm{hr}$ free running period. Peaks appeared at $07 \mathrm{hr}(\sim 66 \mathrm{mg}), 10 \mathrm{hr}(\sim 75 \mathrm{mg}), 12 \mathrm{hr}$ $(\sim 130 \mathrm{mg}), 15 \mathrm{hr}(\sim 56 \mathrm{mg}), 18 \mathrm{hr}(\sim 56 \mathrm{mg}), 21 \mathrm{hr}(\sim 78 \mathrm{mg})$ and next day at $02 \mathrm{hr}(\sim 76 \mathrm{mg})$ and $06 \mathrm{hr}(\sim 76 \mathrm{mg})$. Troughs occurred at $08 \mathrm{hr}(\sim 27 \mathrm{mg}), 11 \mathrm{hr}(\sim 44 \mathrm{mg}), 14$ $\mathrm{hr}(\sim 44 \mathrm{mg}), 16 \mathrm{hr}(\sim 28 \mathrm{mg}), 19 \mathrm{hr}(\sim 42 \mathrm{mg}), 00 \mathrm{hr}(\sim 58$ $\mathrm{mg})$ and next day at $04 \mathrm{hr}(\sim 47 \mathrm{mg})$. Under DD, the trehalose rhythm showed 7 peaks and 7 troughs during the $24 \mathrm{hr}$ free running period. The Peaks appeared at 07 $\mathrm{hr}(\sim 104 \mathrm{mg}), 11 \mathrm{hr}(\sim 68 \mathrm{mg}), 16 \mathrm{hr}(\sim 58 \mathrm{mg}), 19 \mathrm{hr}(\sim 85$ $\mathrm{mg}), 22 \mathrm{hr}(\sim 65 \mathrm{mg})$ and next day at $01 \mathrm{hr}(\sim 88 \mathrm{mg}), 05 \mathrm{hr}$ ( $\sim 65 \mathrm{mg})$, the troughs occurred at $06 \mathrm{hr}(\sim 57 \mathrm{mg}), 08 \mathrm{hr}$ ( $\sim 24 \mathrm{mg}), 15 \mathrm{hr}(\sim 37 \mathrm{mg}), 17 \mathrm{hr}(\sim 38 \mathrm{mg}), 20 \mathrm{hr}(\sim 37 \mathrm{mg})$, $00 \mathrm{hr}(\sim 56 \mathrm{mg})$ and next day at 03-04 hr $(\sim 58 \mathrm{mg})$. The interval between peaks was $2.8 \mathrm{hr}$ under LD, $2.9 \mathrm{hr}$ under LL and $3.1 \mathrm{hr}$ under DD and that between troughs was $2.6 \mathrm{hr}$ under LD, $2.7 \mathrm{hr}$ both under LL and DD. The combined mean interval between peaks and troughs was roughly about $2.7 \mathrm{hr}$ under both $\mathrm{LD}, 2.8 \mathrm{hr}$ under LL and $2.9 \mathrm{hr}$ under DD (Table 1A, B and Table 5).

G ut content: Under LD the trehalose rhythm of the gut content showed 4 peaks and 5 troughs during the $24 \mathrm{hr}$ free running period of the rhythm (Fig.1B). The peaks occurred at $09 \mathrm{hr}(\sim 38 \mathrm{mg}), 14 \mathrm{hr}(\sim 38 \mathrm{mg}), 19 \mathrm{hr}(\sim 38 \mathrm{mg})$ and $22 \mathrm{hr}(\sim 48 \mathrm{mg})$, and the troughs were recorded at 06 $\mathrm{hr}(\sim 9 \mathrm{mg}), 12 \mathrm{hr}(\sim 17 \mathrm{mg}), 18 \mathrm{hr}(\sim 22 \mathrm{mg}) 20 \mathrm{hr}(\sim 31 \mathrm{mg})$ and next day at $04 \mathrm{hr}(\sim 15 \mathrm{mg})$. Under LL, the trehalose rhythm showed 5 peaks and 6 troughs. The peaks occured at 08-10 hr ( 27 mg), $16 \mathrm{hr}(\sim 38 \mathrm{mg}), 20 \mathrm{hr}(\sim 39$ $\mathrm{mg}), 22 \mathrm{hr}(\sim 44 \mathrm{mg})$ and next day at $01 \mathrm{hr}(\sim 26 \mathrm{mg})$. The troughs appeared at $06 \mathrm{hr}(\sim 11 \mathrm{mg}), 11-12 \mathrm{hr}(\sim 19 \mathrm{mg})$, $18 \mathrm{hr}(\sim 27 \mathrm{mg}), 21 \mathrm{hr}(\sim 34 \mathrm{mg}), 00 \mathrm{hr}(\sim 23 \mathrm{mg})$ and next day at $05 \mathrm{hr}(\sim 13 \mathrm{mg})$. Under DD, the trehalose rhythm showed 5 peaks and 6 troughs during the $24 \mathrm{hr}$ free running period of the rhythm. The peaks occured at $07-$ $08 \mathrm{hr}(\sim 27 \mathrm{mg}), 10 \mathrm{hr}(\sim 26 \mathrm{mg}), 15 \mathrm{hr}(\sim 34 \mathrm{mg}), 17 \mathrm{hr}$ ( $39 \mathrm{mg})$ and at $00 \mathrm{hr}(\sim 53 \mathrm{mg})$, the troughs occured at 06 $\mathrm{hr}(\sim 14 \mathrm{mg}), 09 \mathrm{hr}(\sim 23 \mathrm{mg}), 12 \mathrm{hr}(\sim 17 \mathrm{mg}), 16 \mathrm{hr}(\sim 31$ $\mathrm{mg}), 18 \mathrm{hr}(\sim 29 \mathrm{mg})$ and next day at $02 \mathrm{hr}(\sim 35 \mathrm{mg})$. The 

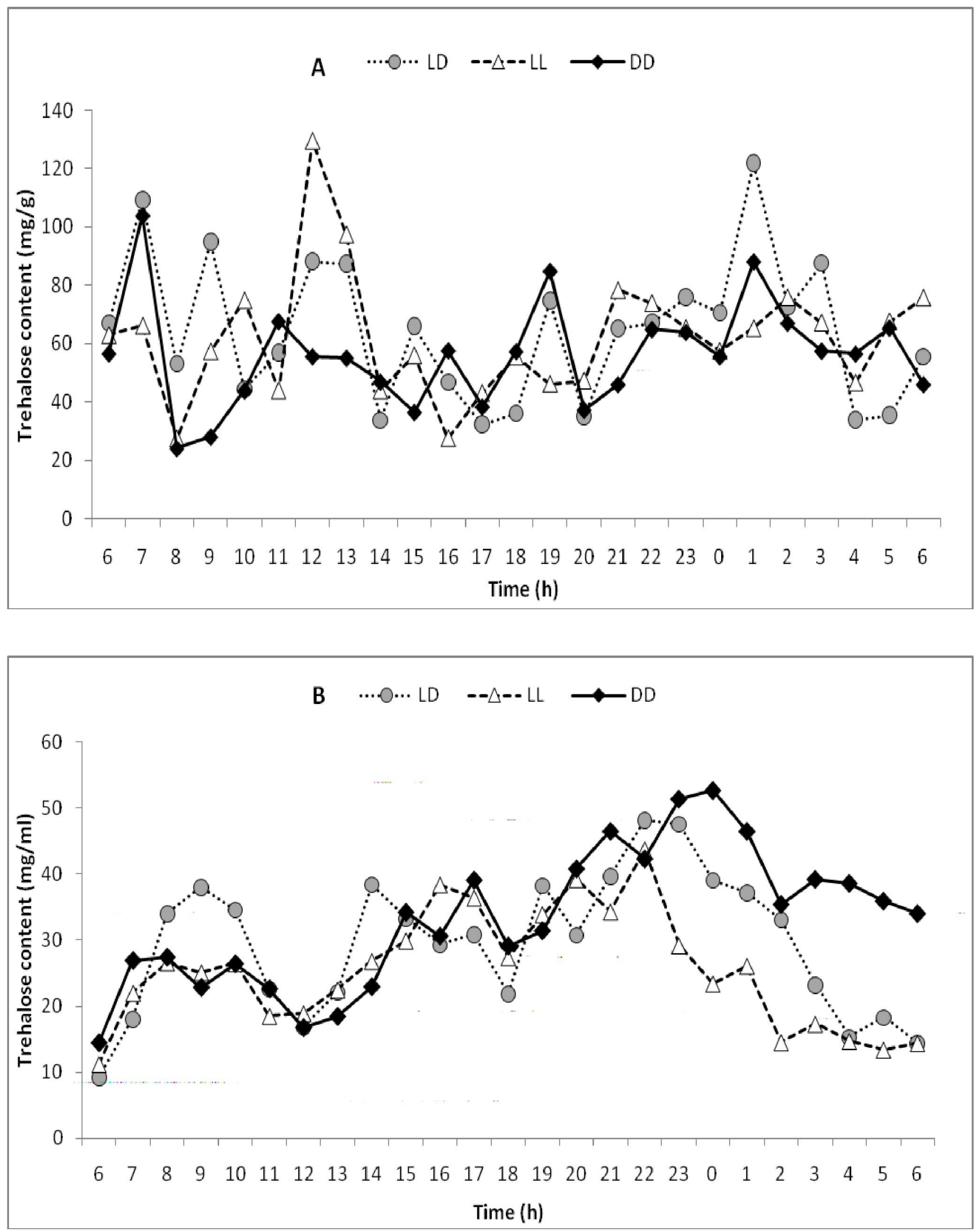

Fig. 1. Phase response curves (PRC S) of the $24 \mathrm{hr}$ circadian trehalose rhythms in the gut wall (A) and gut content (B) of fifth instar larva of B ombyx mori, under $12 \mathrm{hr}$ light: $12 \mathrm{hr}$ dark cycle (LD), continuous light (LL) and continuous dark (DD) conditions. The values expressed in $\mathrm{mg}$ glucose $/ \mathrm{g}$ wet weight of tissue, represent the $24 \mathrm{hr}$ (from 6AM on day 5 to 6AM on day 6) free running time of the circadian rhythm ( $P$ values: $<0.001$ ). 

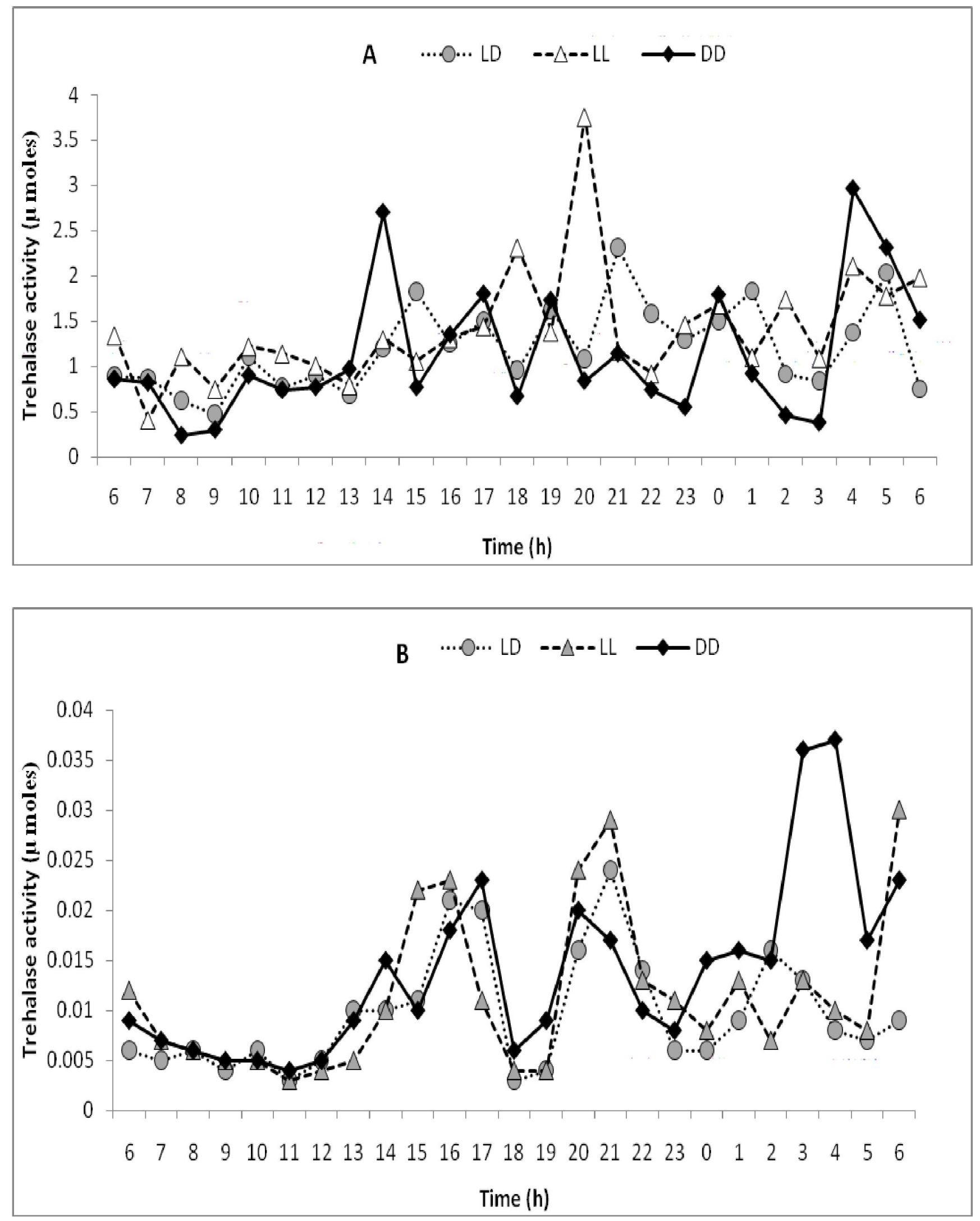

Fig. 2. Phase response curves (PRCS) of the $24 \mathrm{hr}$ circadian trehalase rhythms in the gut wall (A) and gut content (B) of fifth instar larva of Bombyx mori, under $12 \mathrm{hr}$ light: $12 \mathrm{hr}$ dark cycle (LD), continuous light (LL) and continuous dark (DD) condition. The values expressed in $\mu$ moles of glucose /mg trehalose/ hr), represent the $24 \mathrm{hr}$ (from 6AM on day 5 to 6AM on day 6) free running time of the circadian rhythm ( $P$ values: $<0.001$ ). 

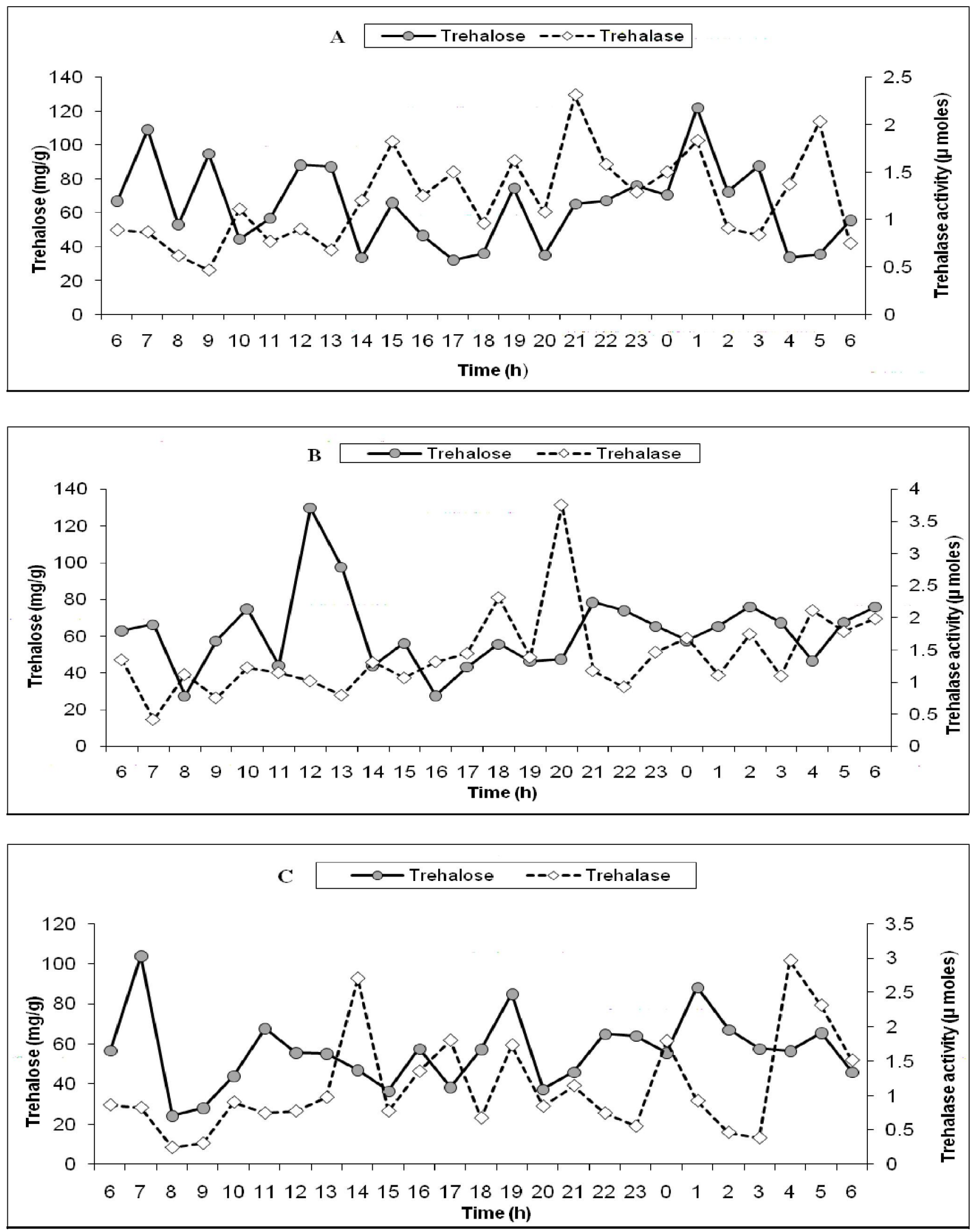

Fig. 3. Circadian changes in trehalose profiles and trehalase activity in the gut wall of the fifth instar larva of B ombyx mori, under (A) $12 \mathrm{hr}$ light: $12 \mathrm{hr}$ dark cycle (LD), (B) continuous light (LL) and (C) continuous dark (D D) conditions. The values expr essed in $\mathrm{mg}$ glucose per gm wet weight of tissue in case of trehalose and i moles of glucose formed/ $\mathrm{mg}$ trehalose/ hr in case of trehalase, represent the $24 \mathrm{hr}$ ( 6 AM on day-5 to 6 A.M on day 6) free running time of the circadian rhythm. (P values: <0.001). 

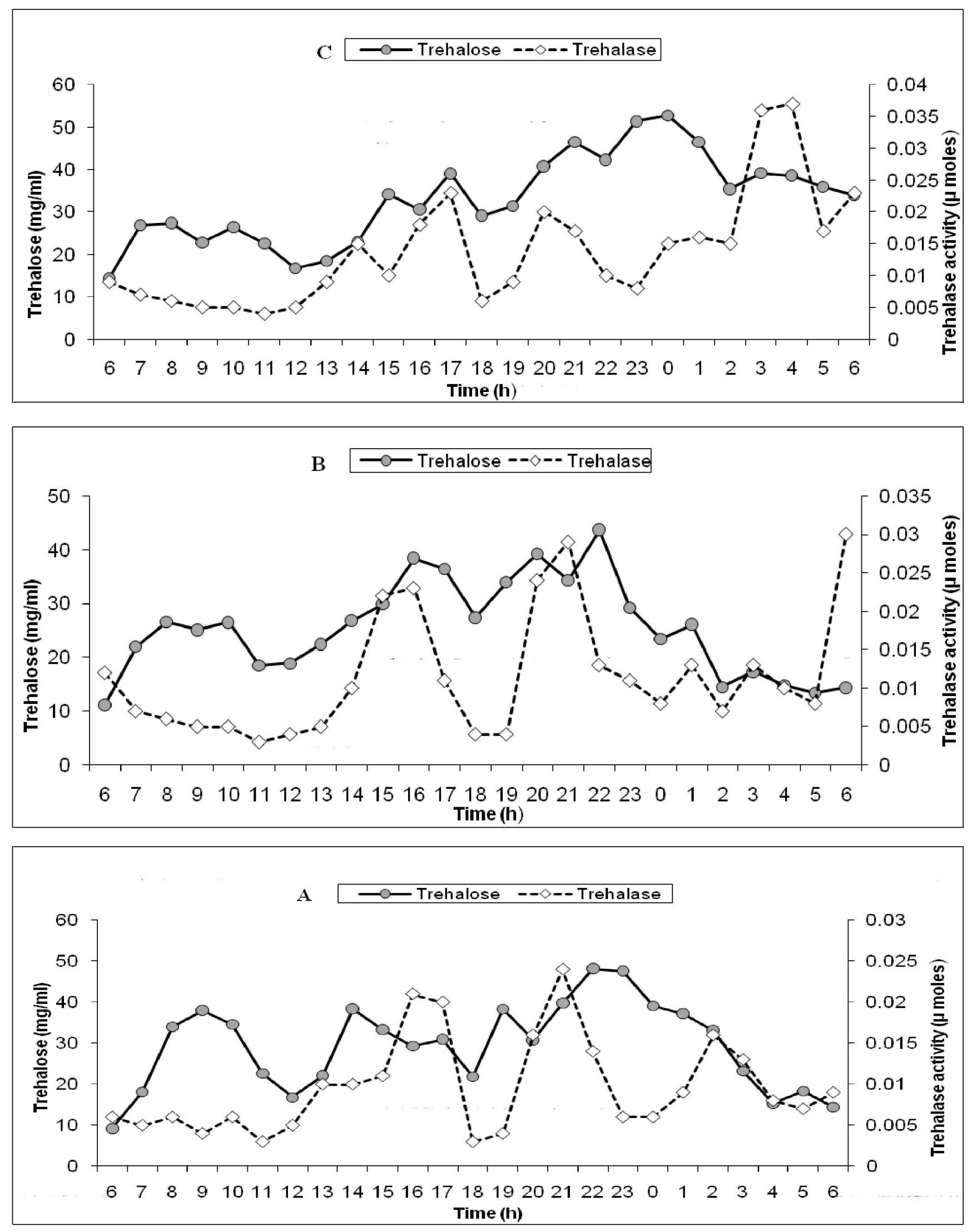

Fig. 4. Circadian changes in trehalose profiles and trehalase activity in the gut content of the fifth instar larva of Bombyx mori, under (A) $12 \mathrm{hr}$ light: $12 \mathrm{hr}$ dark cycle (LD), (B) continuous light (LL) and (C) continuous dark (DD) conditions. The values expressed in $\mathrm{mg}$ glucose per $\mathrm{ml}$ of tissue in case of trehalose and i moles of glucose formed/ $\mathrm{mg}$ trehalose/ $\mathrm{hr}$ in case of trehalase, represent the $24 \mathrm{hr}$ ( 6 AM on day-5 to 6 A.M on day 6 ) free running time of the circadian rhythm. (P values: $<0.001$ ). 
Table 1 (A and B). Interval between peaks (A) and troughs (B) in the levels of trehalose in the gut wall of the fifth instar larva of B.mori during the free running time of the circadian rhythm under $12 \mathrm{hrs} \mathrm{light/} \mathrm{dark} \mathrm{cycle} \mathrm{(LD),} \mathrm{continuous} \mathrm{light} \mathrm{(LL)} \mathrm{and}$ continuous dark (DD) conditions.

A.

\begin{tabular}{lccccccccc}
\hline Photo & No. of & \multicolumn{4}{c}{ Inter val between peaks in hours } & \multicolumn{2}{c}{ M ean interval in } \\
\cline { 2 - 10 } period & peaks & $1-2$ & $2-3$ & $3-4$ & $4-5$ & $5-6$ & $6-7$ & $7-8$ & hours \\
\hline LD & 8 & 2 & 3 & 2 & 4 & 6 & 2 & 3 & 2.8 \\
LL & 8 & 3 & 2 & 3 & 3 & 3 & 5 & 4 & 2.9 \\
DD & 7 & 4 & 5 & 3 & 3 & 3 & 4 & - & 3.1 \\
\hline
\end{tabular}

\begin{tabular}{|c|c|c|c|c|c|c|c|c|c|}
\hline \multicolumn{10}{|l|}{$\bar{B}$. } \\
\hline \multirow{2}{*}{$\begin{array}{l}\text { Photo } \\
\text { period }\end{array}$} & \multirow{2}{*}{$\begin{array}{l}\text { No. of } \\
\text { tr oughs }\end{array}$} & \multicolumn{7}{|c|}{ Inter val between troughs in hour s } & M ean interval in \\
\hline & & $1-2$ & $2-3$ & $3-4$ & $4-5$ & $5-6$ & $6-7$ & $7-8$ & hours \\
\hline$\overline{\mathrm{LD}}$ & 8 & 2 & 2 & 4 & 3 & 2 & 6 & 2 & 2.6 \\
\hline LL & 7 & 3 & 3 & 2 & 3 & 4 & 4 & - & 2.7 \\
\hline DD & 7 & 2 & 7 & 2 & 3 & 4 & 3 & - & 2.7 \\
\hline
\end{tabular}

Source: Fig. 1A.

interval between peaks was about $3.3 \mathrm{hr}$ under LD, $3.0 \mathrm{hr}$ under LL and $3.2 \mathrm{hr}$ under DD and that between troughs was about $4.4 \mathrm{hr}$ under LD, $3.7 \mathrm{hr}$ under LL and $3.3 \mathrm{hr}$ under DD. The combined mean interval between peaks and troughs was about $3.9 \mathrm{hr}$ under LD, $3.4 \mathrm{hr}$ under both LL and DD (Table 2A, B and Table 5).

Circadian trehalase rhythm

Gut wall: Under LD the rhythm of trehalase activity showed 8 peaks and 8 troughs in the gut wall during the $24 \mathrm{hr}$ free running period of the rhythm (Fig.2A). Peaks appeared at $06-07 \mathrm{hr}(\sim 0.89 \mu$ moles $), 10 \mathrm{hr}(1.11 \mu$ moles $)$, $15 \mathrm{hr}(1.82 \mu$ moles $), 17 \mathrm{hr}(1.5 \mu$ moles $), 19 \mathrm{hr}(1.62 \mu$ moles $), 21 \mathrm{hr}(2.31 \mu$ moles $)$ and next day at $01 \mathrm{hr}(1.83 \mu$ moles) and $05 \mathrm{hr}(2.03 \mu$ moles $)$ and troughs appeared at $09 \mathrm{hr}(0.47 \mu$ moles $), 13 \mathrm{hr}(0.68 \mu$ moles $), 16 \mathrm{hr}(1.25 \mu$ moles $), 18 \mathrm{hr}(0.96 \mu$ moles $), 20 \mathrm{hr}(1.08 \mu$ moles $), 23 \mathrm{hr}$ ( $1.29 \mu$ moles $)$ and next day at $03 \mathrm{hr}(0.84 \mu$ moles $)$ and 06 $\mathrm{hr}(0.75 \mu$ moles $)$. Under LL the rhythm showed 10 peaks and 9 troughs during the $24 \mathrm{hr}$ free running time. The first peak appeared at $06 \mathrm{hr}(1.34 \mu$ moles $), 08 \mathrm{hr}(1.11 \mu$

moles $), 10 \mathrm{hr}(1.22 \mu$ moles $), 14 \mathrm{hr}(1.30 \mu$ moles $), 18 \mathrm{hr}$ (2.31 $\mu$ moles), $20 \mathrm{hr}(3.75 \mu$ moles $), 00 \mathrm{hr}$ (1.68 $\mu$ moles $)$ and next day at $02 \mathrm{hr}(1.74 \mu$ moles $), 04 \mathrm{hr}$ (2.11 $\mu$ moles $)$ and $06 \mathrm{hr}(1.98 \mu$ moles $)$ and the troughs occured at $07 \mathrm{hr}$ (0.41 $\mu$ mole), $09 \mathrm{hr}(0.75 \mu$ moles $), 13 \mathrm{hr}(0.79 \mu$ moles $), 15$ hr (1.06 $\mu$ moles $), 19 \mathrm{hr}(1.38 \mu$ moles $), 22 \mathrm{hr}(0.92 \mu$ moles $)$ and next day at $01 \mathrm{hr}(1.10 \mu$ moles $), 03 \mathrm{hr}(1.09 \mu$ moles $)$ and at $05 \mathrm{hr}(1.78 \mu$ moles $)$. Under DD, the trehalase activity rhythm showed 7 peaks and 7 troughs during the $24 \mathrm{hr}$ free running period (Fig.2A). The peaks appeared at $06 \mathrm{hr}(0.86 \mu$ moles $) 14 \mathrm{hr}(2.70 \mu$ moles $), 17 \mathrm{hr}$ (1.80 $\mu$ moles), $19 \mathrm{hr}(1.73 \mu$ moles $), 21 \mathrm{hr}(1.14 \mu$ moles $)$, $00 \mathrm{hr}(1.79 \mu$ moles $)$ and next day at $04 \mathrm{hr}(2.96 \mu$ moles $)$ and the troughs occured at $08 \mathrm{hr}(0.24 \mu$ moles $), 15 \mathrm{hr}$ (0.77 $\mu$ moles $), 18 \mathrm{hr}(0.67 \mu$ moles $), 20 \mathrm{hr}(0.84 \mu$ moles $)$, $23 \mathrm{hr}(0.55 \mu$ moles $)$ and next day at $03 \mathrm{hr}(0.38 \mu$ moles $)$ and $06 \mathrm{hr}(1.51 \mu$ moles $)$. The interval between peaks was about $2.8 \mathrm{hr}$ under LD, $2.4 \mathrm{hr}$ under LL and $3.1 \mathrm{hr}$ under DD and that between troughs was about $2.5 \mathrm{hr}$ under LD, $2.4 \mathrm{hr}$ under LL and $3.0 \mathrm{hr}$ under DD. The combined mean

Table 2 ( $A$ and $B$ ). Interval between peaks (A) and troughs (B) in the levels of trehalose in the gut content of the fifth instar larva of B.mori during the free running time of the circadian rhythm under 12 hrs light/ dark cycle (LD), continuous light (LL) and continuous dark (DD) conditions. A.

\begin{tabular}{lccccccc}
\hline & Photo & No. of & \multicolumn{4}{c}{ Interval between peaks in hours } & M ean inter val \\
period & peaks & $1-2$ & \multicolumn{2}{c}{$2-3$} & $3-4$ & $4-5$ & 3.3 \\
in hours
\end{tabular}

Source: Fig. 1B. 
Table 3 (A and B). Interval between peaks (A) and troughs (B) in the activity levels of trehalase in the gut wall of the fifth instar larva of $B$. mori during the free running time of the circadian rhythm under $12 \mathrm{hr}$ light/ dark cycle (LD), continuous light (LL) and continuous dark (DD) conditions.

A.

\begin{tabular}{|c|c|c|c|c|c|c|c|c|c|c|c|}
\hline \multirow{2}{*}{$\begin{array}{l}\text { Photo } \\
\text { period }\end{array}$} & \multirow{2}{*}{$\begin{array}{l}\text { No. of } \\
\text { peaks }\end{array}$} & \multicolumn{9}{|c|}{ Inter val between peaks in hours } & \multirow{2}{*}{$\begin{array}{c}\text { M ean inter val in } \\
\text { hours }\end{array}$} \\
\hline & & $1-2$ & $2-3$ & $3-4$ & $4-5$ & $5-6$ & $6-7$ & $7-8$ & 8-9 & $9-10$ & \\
\hline LD & 8 & 3 & 5 & 2 & 2 & 2 & 4 & 4 & - & - & 2.8 \\
\hline LL & 10 & 2 & 2 & 4 & 4 & 2 & 4 & 2 & 2 & 2 & 2.4 \\
\hline DD & 7 & 8 & 3 & 2 & 2 & 3 & 4 & - & - & - & 3.1 \\
\hline
\end{tabular}

B.

\begin{tabular}{|c|c|c|c|c|c|c|c|c|c|c|}
\hline \multirow{2}{*}{$\begin{array}{l}\text { Photo } \\
\text { period }\end{array}$} & \multirow{2}{*}{$\begin{array}{l}\text { No. of } \\
\text { troughs }\end{array}$} & \multicolumn{8}{|c|}{ Inter val between troughs in hours } & \multirow{2}{*}{$\begin{array}{c}\text { M ean interval in } \\
\text { hours }\end{array}$} \\
\hline & & $1-2$ & $2-3$ & $3-4$ & $4-5$ & $5-6$ & $6-7$ & $7-8$ & $8-9$ & \\
\hline LD & 8 & 4 & 3 & 2 & 2 & 3 & 3 & 3 & - & 2.5 \\
\hline LL & 9 & 2 & 4 & 2 & 4 & 3 & 3 & 2 & 2 & 2.4 \\
\hline $\mathrm{DD}$ & 7 & 6 & 3 & 2 & 3 & 4 & 3 & - & - & 3.0 \\
\hline
\end{tabular}

\section{Source: Fig. $2 \mathrm{~A}$}

interval between peaks and troughs was about $2.7 \mathrm{hr}$ under LD, 2.4 hr under LL and 3.1 hr under DD (Table 3A, B and Table 6).

G ut content: Under LD, the trehalase activity showed 4 peaks and 4 troughs in the gut content during the $24 \mathrm{hr}$ free running period of the rhythm (Fig.2B). Peaks appeared at $16 \mathrm{hr}(0.021 \mu$ moles $), 21 \mathrm{hr}(0.024 \mu$ moles $)$ and next day at $02 \mathrm{hr}(0.016 \mu$ moles $)$, and $06 \mathrm{hr}(0.009 \mu$ moles $)$, and troughs appeared at $06 \mathrm{hr}(0.006 \mu$ moles $)$, 18-19 hr ( 0.004 $\mu$ moles $), 23-00 \mathrm{hr}(0.006 \mu$ moles $)$ and next day $05 \mathrm{hr}(0.007 \mu$ moles $)$.Under LL the rhythm showed 5 peaks and 5 troughs, the peaks appeared at 15$16 \mathrm{hr}$ ( $\sim 0.023 \mu$ moles $), 21 \mathrm{hr}(0.029 \mu$ moles $)$ and next day at $01 \mathrm{hr}(0.013 \mu$ moles $), 03 \mathrm{hr}(0.013 \mu$ moles $)$ and $06 \mathrm{hr}$ $(0.030 \mu$ moles $)$ and the troughs at $06 \mathrm{hr}(0.012 \mu$ moles $)$, $18-19 \mathrm{hr}(0.004 \mu$ moles $), 00 \mathrm{hr}(0.008 \mu$ moles $)$ and next day at $02 \mathrm{hr}(0.007 \mu$ moles $)$ and $05 \mathrm{hr}(0.008 \mu$ moles $)$. Under DD the trehalase activity rhythm showed 4 peaks and 4 troughs during the $24 \mathrm{hr}$ free running period. The peaks appeared at $17 \mathrm{hr}(0.023 \mu$ moles $), 20 \mathrm{hr}(0.020 \mu$ moles) and next day at $04 \mathrm{hr}(0.037 \mu$ moles $)$ and $06 \mathrm{hr}$ $(0.023 \mu$ moles $)$ and the troughs appeared at $06 \mathrm{hr}(0.009 \mu$ moles $), 18 \mathrm{hr}(0.006 \mu$ moles $), 23 \mathrm{hr}(0.008 \mu$ moles $)$ and next day at $05 \mathrm{hr}(0.017 \mu$ moles $)$. The interval between peaks was about $3.5 \mathrm{hr}$ under LD and $3.0 \mathrm{hr}$ under both LL and DD and that between troughs was about $5.3 \mathrm{hr}$ under LD, $4.6 \mathrm{hr}$ under LL and $5.8 \mathrm{hr}$ under DD. The combined mean interval between peaks and troughs was about $4.4 \mathrm{hr}$ under both LD and DD and $3.8 \mathrm{hr}$ under LL (Table 4A, B and Table 6).

\section{DISCUSSION}

Trehalose is the most common blood sugar in insects. It is synthesized from the glucose derived from the dietary carbohydrates such as the pectin, xylan, cellulose, sucrose and starch present in the mulberry leaf and later transported to the gut wall, where it is stored either in the same form or in the form of glycogen (Yamashita, 1965; Yamashita and Hasegawa, 1974; Anand et al., 2010).

Table 4 (A and B). Interval between peaks (A) and troughs (B) in the activity levels of trehalase in the gut content of the fifth instar larva of B.mori during the free running time of the circadian rhythm under $12 \mathrm{hr}$ light/ dark cycle (LD), continuous light (LL) and continuous dark (DD) conditions.

A.

\begin{tabular}{lcccccc}
\hline Photo & No. of & \multicolumn{3}{c}{ Interval between peaks in hours } & \multicolumn{2}{c}{ M ean interval in } \\
\cline { 2 - 6 } period & Peaks & $1-2$ & $2-3$ & $3-4$ & $4-5$ & 3.5 \\
\hline LD & 4 & 5 & 5 & 4 & - & 3.0 \\
LL & 5 & 5 & 4 & 2 & 3 & 3.0 \\
DD & 4 & 3 & 7 & 2 & - & \\
\hline
\end{tabular}

\begin{tabular}{|c|c|c|c|c|c|c|c|}
\hline \multicolumn{7}{|l|}{$B$} & \\
\hline \multirow{2}{*}{$\begin{array}{l}\text { Photo } \\
\text { period }\end{array}$} & \multirow{2}{*}{$\begin{array}{l}\text { No. of } \\
\text { troughs }\end{array}$} & \multicolumn{5}{|c|}{ Inter val between troughs in hours } & \multirow{2}{*}{$\begin{array}{c}\text { M ean interval ir } \\
\text { hours }\end{array}$} \\
\hline & & $1-2$ & $2-3$ & $3-4$ & $4-5$ & $5-6$ & \\
\hline LD & 4 & 12 & 4 & 5 & - & - & 5.3 \\
\hline LL & 5 & 13 & 5 & 2 & 3 & - & 4.6 \\
\hline DD & 4 & 12 & 5 & 6 & - & - & 5.8 \\
\hline
\end{tabular}

Source: Fig. 2B. 
Table 5. Comparative analysis of the phase response curves of the trehalose rhythm in the gut wall and gut content of the fifth instar larva of B.mori, under $12 \mathrm{hr}$ light / dark cycle (LD), continuous light (LL) and continuous dark (DD) conditions.

\begin{tabular}{|c|c|c|c|c|c|c|}
\hline \multirow[t]{2}{*}{ Par ameter } & \multicolumn{3}{|c|}{ Gut wall } & \multicolumn{3}{|c|}{ G ut content } \\
\hline & $L D$ & $\mathrm{LL}$ & DD & LD & $\mathrm{LL}$ & DD \\
\hline No. of peaks & 8 & 8 & 7 & 4 & 5 & 5 \\
\hline No. of troughs & 8 & 7 & 7 & 5 & 6 & 6 \\
\hline $\begin{array}{l}\text { Mean interval b/w } \\
\text { peaks (hr) }\end{array}$ & 2.8 & 2.9 & 3.1 & 3.3 & 3.0 & 3.2 \\
\hline $\begin{array}{l}\text { Mean interval b/w } \\
\text { troughs (hr) }\end{array}$ & 2.6 & 2.7 & 2.7 & 4.4 & 3.7 & 3.3 \\
\hline $\begin{array}{l}\text { Combined mean } \\
\text { interval b/w peaks } \\
\text { and troughs }(\mathrm{hr})\end{array}$ & 2.7 & 2.8 & 2.9 & 3.9 & 3.4 & 3.4 \\
\hline $\begin{array}{l}\text { Probable no. of } \\
\text { TS/TR cycles }\end{array}$ & 8 & 8 & 7 & 4 & 5 & 5 \\
\hline $\begin{array}{l}\text { Approximate time } \\
\text { taken for each TS/TR } \\
\text { cycles (hr) }\end{array}$ & $\begin{array}{c}3.0 \\
(24 / 8=3.0)\end{array}$ & $\begin{array}{c}3.0 \\
(24 / 8=3.0)\end{array}$ & $\begin{array}{c}3.4 \\
(24 / 7=3.4)\end{array}$ & $\begin{array}{c}6.0 \\
(24 / 4=6.0)\end{array}$ & $\begin{array}{c}4.8 \\
(24 / 5=4.8)\end{array}$ & $\begin{array}{c}4.8 \\
(24 / 5=4.8)\end{array}$ \\
\hline $\begin{array}{l}\text { Free running time of } \\
\text { rhythm (hr) }\end{array}$ & $\begin{array}{c}24 \\
(3 \times 8=24)\end{array}$ & $\begin{array}{c}24 \\
(3 \times 8=24)\end{array}$ & $\begin{array}{c}27.2 \\
(3.4 \times 8=27.2)\end{array}$ & $\begin{array}{c}24 \\
(6 \times 4=24)\end{array}$ & $\begin{array}{c}19.2 \\
(4.8 \times 4=19.2)\end{array}$ & $\begin{array}{c}19.2 \\
(4.8 \times 4=19.2)\end{array}$ \\
\hline Mean peak value & 87.2 & 76.6 & 76.0 & 40.7 & 34.7 & 35.9 \\
\hline
\end{tabular}

Source: Fig. 1A and B; TS Cycles: Trehalose synthetic cycles; TR cycles: Trehalose release cycles

The digestive system of Bombyx mori is principally concerned with the digestion and absorption of dietary nutrients present in the mulberry leaf. The principal nutrients of mulberry leaf include carbohydrates which are digested and absorbed as glucose molecules and finally assimilated in the form of storage sugar called trehalose in the fat body and gut wall cells (Thompson, 2003; Narayanaswamy and Shankar, 2010; Shivakumar and Shamitha, 2011; Lokesh et al., 2012). The trehalose, so derived is degraded to glucose by an enzyme called trehalase, and used both as a means of energy source and for the maintenance of homeostasis (Azuma and Yamashita, 1985; Su et al., 1993; Nath, 2000). More importantly, trehalose levels in the silkworm tissues are homeostatically controlled by the complementary action of two enzymes, viz, trehalose phosphate synthase that synthesizes trehalose from glucose and trehalase that hydrolyses trehalose to glucose (Candy and Kilby, 1961; Thompson, 2003). The dynamic equilibrium between trehalose and glucose appears to be maintained by light sensitive time giver in a circadian fashion much like that of many other biochemical constituents (Kostal and Shimada, 2001; Iwai et al., 2006). Our study on the circadian profiles of trehalose and trehalase activity confirms the exsistence of circadian biochemical rhythms in the B. mori, even at the level of digestive system, similar to those in other tissues such as the silk gland, fat body, muscle and haemolymph (Sailaja and Sivaprasad, 2010, a, b., Sailaja and Sivaprasad, 2011; Sivaprasad and Sailaja, 2011; Sailaja et al., 2011; Bhuvaneswari and
Sivaprasad, 2012). The circadian trehalose and trehalase data, presented as peaks and troughs in PRC s (Figs. 1 and 2 and Tables 1 to 6 ) are analyzed in the following terms. The number of peaks in trehalose rhythm is interpreted in terms of the number of trehalose synthetic cycles (TS cycles) in the gut wall and number of trehalose release cycles (TR cycles) in the gut content. Similarly, the number of peaks in trehalase activity is interpreted in terms of trehalase enzyme synthetic cycles (TES cycles) in the gut wall and trehalase enzyme release cycles (TER cycles) in the gut content. In both the compartments of digestive system (gut wall and gut lumen), the height of peaks are interpreted in terms of intensity of synthetic/ release cycles and the mean peak value in terms of the average levels of trehalose or trehalase activity maintained during the $24 \mathrm{hr}$ free running time of the rhythm. At the same time the combined mean intervals between peaks and troughs are considered as the time taken for completion of synthetic / release cycles of both trehalose and trehalase (Tables 5 and 6).

Circadian tr ehalose rhythm

Gut wall: Most of the trehalose found in the epithelial cells of the gut wall is apparently synthesized from the dietary glucose (Thompson, 2003). The trehalose rhythm maintains 8 TS cycles under LD and LL with duration of $3.0 \mathrm{hr}$ each and 7 cycles under DD each with a duration of $3.4 \mathrm{hr}$. Thus, DD condition modulates trehalose synthesis by extending the duration of each cycle by 24 min (from $3.0 \mathrm{hr}$ to $3.4 \mathrm{hr}$ ). Because of the prolongation of the duration of all the TS cycles in a day, the $24 \mathrm{hr}$ free 
Table 6. Comparative analysis of the phase response curves of the trehalase rhythm in the gut wall and gut content of the fifth instar larva of B.mori, under 12hr light / dark cycle (LD), continuous light (LL) and continuous dark (DD) conditions.

\begin{tabular}{|c|c|c|c|c|c|c|}
\hline \multirow[t]{2}{*}{ Parameter } & \multicolumn{3}{|c|}{ Gut wall } & \multicolumn{3}{|c|}{ Gut content } \\
\hline & LD & $\mathrm{LL}$ & $\mathrm{DD}$ & LD & $\mathrm{LL}$ & DD \\
\hline No. of Peaks & 8 & 10 & 7 & 4 & 5 & 4 \\
\hline No .of Troughs & 8 & 9 & 7 & 4 & 5 & 4 \\
\hline $\begin{array}{l}\text { Mean interval b/w } \\
\text { Peaks (hr) }\end{array}$ & 2.8 & 2.4 & 3.1 & 3.5 & 3.0 & 3.0 \\
\hline $\begin{array}{l}\text { Mean interval b/w } \\
\text { Troughs (hr) }\end{array}$ & 2.5 & 2.4 & 3.0 & 5.3 & 4.6 & 5.8 \\
\hline $\begin{array}{l}\text { Combined mean } \\
\text { interval b/w Peaks } \\
\text { and Troughs (hr) }\end{array}$ & 2.7 & 2.4 & 3.1 & 4.4 & 3.8 & 4.4 \\
\hline $\begin{array}{l}\text { Probable no. of } \\
\text { TES/TER cycles }\end{array}$ & 8 & 10 & 7 & 4 & 5 & 4 \\
\hline $\begin{array}{l}\text { Approximate time } \\
\text { taken for each } \\
\text { TES/TER cycles (hr) }\end{array}$ & $\begin{array}{c}3.0 \\
(24 / 8=3)\end{array}$ & $\begin{array}{c}2.4 \\
(24 / 10=2.4)\end{array}$ & $\begin{array}{c}3.4 \\
(24 / 7=3.4)\end{array}$ & $\begin{array}{c}6.0 \\
(24 / 4=6)\end{array}$ & $\begin{array}{c}4.8 \\
(24 / 5=4.8)\end{array}$ & $\begin{array}{c}6.0 \\
(24 / 4=6)\end{array}$ \\
\hline $\begin{array}{l}\text { Free running time of } \\
\text { Rhythm (hr) }\end{array}$ & $\begin{array}{c}24 \\
(3 \times 8=24)\end{array}$ & $\begin{array}{c}19.2 \\
(2.4 \times 8=19.2)\end{array}$ & $\begin{array}{c}27.2 \\
(3.4 \times 8=27.2)\end{array}$ & $\begin{array}{c}24 \\
(6 \times 4=24)\end{array}$ & $\begin{array}{c}19.2 \\
(4.8 \times 4=19.2)\end{array}$ & $\begin{array}{c}24 \\
(6 \times 4=24)\end{array}$ \\
\hline Mean Peak value & 1.64 & 1.85 & 1.85 & 0.033 & 0.022 & 0.026 \\
\hline
\end{tabular}

Source: Fig. 2A and B; TES cycles: Trehalase enzyme synthetic cycles; TER cycles: Trehalase enzyme release cycles

running time of trehalose rhythm under LD and LL is clock-shifted to $27.2 \mathrm{hr}$ under DD (Table 5). Further analysis of peaks interms of their height reveals that the intensity of trehalose synthesis is high during scotopic (dark) phase of the day compared to photic (light) phase. Evidently, intense trehalose synthesis occurred thrice (at $07 \mathrm{hr}, 19 \mathrm{hr}$ and 01-02 hr), under DD, twice (at 07-13 hr and 01-03 hr) under LD and only one (at12-13hr) under LL (Fig.1 A). In addition, the photoperiod also affects the mean peak value (MPVs; i. e ., the average of all peaks) of trehalose. The MPV of the trehalose is significantly higher under LD $(87.2 \mathrm{mg})$ and moderate under LL and DD ( 76.0 mg each).Our study indicates that both light and dark cues are necessary for the maintenance of constant levels of trehalose in tissues during the free running time of the rhythm as presumed by Syrova et al., 2003; Iwai et al., 2006; and Fonagy, 2009. This obviously, is done by stimulating the synthesis of trehalose during the night and its utilization as energy source during the day. However, the exposure of silkworm larvae to prolonged light and dark conditions disturbs the balance between synthesis and utilization of trehalose as an energy source in metabolism.

Gut content: Gut content is the rich source of proteins, carbohydrates, lipids, digestive enzymes and many other biochemical constituents derived from the mulberry leaves and glandular epithelial cells of the gut wall. Though trehalose is not a regular constituent of the gut content, it is known to be leaked into the gut lumen from the epithelial cells of gut wall and helps in the maintenance of osmotic gradient between the two compartments of digestive system (Wyatt, 1967; Ito, 1972; Anand et al., 2010). The trehalose release through leakage obviously follows a cyclic path, referred to as trehalose release cycles (TR cycles) in this report. In the gut content trehalose rhythm maintains 4 TR cycles with duration of $6.0 \mathrm{hr}$ each under LD and 5 TR cycles under LL and DD with duration of $4.8 \mathrm{hr}$ each. Thus, LL and DD conditions modulate the TR cycles by reducing the duration of each TR cycle by $1.2 \mathrm{hr}$ (from $6.0 \mathrm{hr}$ to $4.8 \mathrm{hr}$ ). Because of this reason, the free running time of trehalose rhythm runs on $19.2 \mathrm{hr}$ cycle instead of normal 24 hours. Within the rescheduled rhythm, the timing of its active leakage is synchronized with the availability of light. Accordingly, the active leakages occured (at 08-10 hr, 14-15 hr and 22-00 under LD, at 08-10hr, 16-17 $\mathrm{hr}$ and 20-23 hr under LL, and at 07-10hr, $15-17 \mathrm{hr}$ and 21-01 hr under DD). Nevertheless, relatively optimal levels (Higher mean peak values) of trehalose $(\sim 41 \mathrm{mg})$ were consistently maintained win the gut content under LD compared to those of LL and DD ( $35 \mathrm{mg}$ each), as in gut wall cells (Table 5). This supports our earlier finding that both light and dark cues are necessary for the maintenance of carbohydrate energy reserves in silkworm tissues, in which such reserves are synthesized in dark phases and predominantly utilized in the light phase of the day (Bhuvaneswari and Sivaprasad, 2012). 


\section{Circadian tr ehalase rhythm}

Gut wall: The gut wall is the primary source of synthesis for two forms of trehalase (Tre-1 and Tre-2) that ensures continuous availability of glucose by enzymatic hydrolysis of trehalose and that meets the energy requirements of peristalsis (Azuma and Yamashita, 1985; Su et al., 1993; Nath, 2000). As demonstrated in the present study, this enzyme rhythm maintains 8 trehalase enzyme synthetic cycles (TES cycles) under LD with a duration of $3.0 \mathrm{hr}$ each, 10 cycles under LL with a duration of 2.4 $\mathrm{hr}$ each and 7 cycles under DD with a duration of $3.4 \mathrm{hr}$ each (Fig. 2A). Thus, LL condition modulates the enzyme rhythm by reducing time required for each synthetic cycle by $36 \mathrm{~min}$ (from $3.0 \mathrm{hr}$ to $2.4 \mathrm{hr}$ ), while the DD condition does so by extending it by $24 \mathrm{~min}$ (from $3.0 \mathrm{hr}$ to $3.4 \mathrm{hr}$ ). Due to shortening and extension of the duration of TES cycles the $24 \mathrm{hr}$ free running time of the rhythm is clock shifted to $19.2 \mathrm{hr}$ under LL and 27.2 hour under DD. Clearly within the daily rhythm, the enzyme showed 3 active synthetic phases under LD (at $15 \mathrm{hr}, 21-01 \mathrm{hr}$ and $05 \mathrm{hr}$ ), one under LL (at $20 \mathrm{hr}$ ) and two under DD at (14 hr and 04-05 hr). Irrespective of the timing of its active synthesis the trehalase showed higher activity levels (represented in the form of higher MPVs), both under LL and DD conditions (1.85 $\mu$ moles each) compared to that under LD (1.64 $\mu$ moles) (Table 6). Evidently, both the light and dark conditions stimulate trehalase synthesis in the gut wall cells, much like that of silk protein synthesis in the silk gland (Sailaja and Sivaprasad, 2010a,b).

Gut content: Trehalase is produced and released into the gut lumen along with the other digestive enzymes in tracer amounts. The remnant of trehalase activity found in the gut content has been implicated in extracellular digestion of trehalose that diffuses there from the haemolymph and its recovery back into the system and thus prevents its excretion. It also facilitates the continuous supply of glucose into the haemolymph of non-feeding silkworms (Wyatt, 1967; Gilby et al., 1967; Azuma and Yamashita, 1985). Thus trehalose provides energy source during starvation and also facilitates the regulation of homeostatic mechanism among different tissues and organs (Nagasawa et al., 1990; Satake et al., 1997; Iwami, 2000). The trehalase rhythm in the gut content represented as trehalase enzyme release cycles (TER cycles) showed 4 cycles under both LD and DD each with a duration of $6.0 \mathrm{hr}$ each and 5 cycles under LL each with a duration of $4.8 \mathrm{hr}$. Notably, the LL condition reduced the duration of each TER cycle by $1.2 \mathrm{hr}$ (from $6.0 \mathrm{hr}$ to $4.8 \mathrm{hr}$ ) (Fig. 2B) and thus, supports the view that light stimulates trehalase release (Fonagy, 2009). Due to stimulatory effect of light, the $24 \mathrm{hr}$ trehalase rhythm has been rescheduled to operate on shorter duration of $19.2 \mathrm{hr}$ under LL (Table 6). Within the free running time, irrespective of number of enzyme release cycles, three active release phases (high peaks) occurred at different timings under LD ( 16-17 hr, $21 \mathrm{hr}$, $02 \mathrm{hr})$, LL (15-16 hr, 20-21 hr, $06 \mathrm{hr}$ ) and DD (17 hr, $20 \mathrm{hr}$, 03-04 hr). However a higher mean peak value of trehalase activity was observed under $\operatorname{LD}(0.033 \mu$ moles $)$ followed by a moderate value under DD $(0.026 \mu$ moles $)$ and a lower activity under LL $(0.022 \mu$ moles $)$. Though the exact mechanism of circadian regulation is not known, it is presumed that the digestive system of $B$. mori maintains an intrinsic time keeping system that comprises light-sensitive peripheral clocks in its gut wall. Probably these clocks modulate circadian digestive rhythm through their ability to detect and respond to the light cues of the environment (Kostal and Shimida, 2001; Saunders, 2002; Syrova et al., 2003; Allada and Emery, 2009; Hirayama and Sessone- Corsi, 2009; Iwai et al., 2006). This obviously, manifests in the form of circadian changes in the rate of synthesis and release of trehalose and its utilization through trehalase activity in a time dependent manner in B. mori.

Trehalose rhythm versus trehalase rhythm: By and large the trehalose and trehalase rhythm showed inverse relationships with each other throughout the free running time in both the compartments of digestive system under three photoperiodic conditions; LD, LL and DD (Figs. 3 and 4). The peaks in one constituent were accompanied by troughs in the other. For example, the peaks in trehalose levels and troughs in trehalase activity in the gut wall at 06-13 hr and 01-06 hr under LD, 06-15 hr and 21-06 hr under LL, 06-13 hr and 18-03 $\mathrm{hr}$ under DD and those in the gut content at $06-15 \mathrm{hr}$, 22-06 hr under LD, 06-02 hr both LL and DD indicate the probable timing of active phases of trehalose synthesis from sucrose - rich mulberry leaves on one hand and its availability through hormone-induced glycogen breakdown in the fat body and haemolymph on the other (Jungries, 1980; Goldsworthy and Gade, 1983; Oda et al., 2000; Thompson, 2003). Simultaneously decline in trehalose activity is attributable to the availability of dietary glucose which has an inhibitory effect on the formal (Thompson, 2003). Conversely, troughs in the trehalose levels and peaks in trehalase activity in the gut wall at 14-00 hr under LD, 16-20 hr under LL, 14-17 hr and 04-06 hr under DD (Fig.3A,B,C) and those in the gut content at 16-21 hr under LD, 03-06 hr both under LL and DD (Figs.4A,B,C) reflect the probable role of membrane bound trehalases in maintaining the glucose concentration gradient across the gut by hydrolyzing the trehalose that results from glycogen breakdown under the influence of insulin like peptides (Wyatt, 1967; Nagasawa et al., 1990; Satake et al., 1997; Satake et al., 1999; Iwami, 2000). The circadian changes in the levels of trehalose and trehalase in the silkworm require more correlational studies from physiology and nutrition. 


\section{REFERENCES}

Allada, R. and Emery, P. (2009). Genetic regulation of circadian rhythms in Drosophila. (pp 655-661), Encyclopedia of Neuroscience.

Anand, A .A. P., Vennison, S. J., Sankar, S.G., Prabhu, D.I.G., Vasan, P.T., Raghuraman,T., Geoffrey, C. J., Vendan, S. E. (2010). Isolation and characterization of bacteria from the gut of Bombyx mori that degrade Cellulose, xylan, pectin and starch and their impact on digestion. J. Insect. Sci., 10:107.

Azuma, M. and Yamashita, O. (1985). Cellular localization and proposed function of midgut trehalase in the silkworm larva, B ombyx mori. Tissue and C ell, 17: 539-551.

Banaroudj, N., Lee. D.H. and Goldberg, A.L. (2001). Trehalose accumulation during cellular stress protects cells and cellular proteins from damage by oxygen radicals. J .Biol.C hem., 276: 24261-24267.

Becker, A., Schloder, P., Steele, J.E. and Wegener, G. (1996). The regulation of trehlose metabolism in insects. Experientia., 52: 433-439.

Behroozi, E. (2010). Study on the nutritional reserves and cold hardiness of over wintering larvae of pistachio white leaf borer, 0 cneria terebintina (Lepidoptera: lymantriidae) in Rafsanjan township and physiological evaluation of some IGRs against the larvae. M.Sc. thesis. Vali-e-A sr University of Raf Sanjan, Iran.

Bhuvaneswari, E. and Sivaprasad, S. (2012). Impact of photoperiod on circadian protein and protease rhythms in the digestive system of Silkworm, Bombyx mori. The Bioscan, 7: 175-183.

Bolat, I. (2008). The importance of trehalose in brewing yeast survival. Innovative Romanian food Biotechnology, 2: 1-10.

Candy, D.J. and Kilby, B. A. (1961). The biosynthesis of trehalose in the locust fatbody. Biochem. J ., 78: 531-536.

Dahlman, D.L. (1971). Purification and properties of trehalase from tobacco hornworm larvae. J .Insect.Physiol., 17:1677-1689.

Egorova, T.A. and Khomidov, K.S. (1991). Purification and properties of membrane bound trehalase from silkworm eggs. Biochemistry (Moscow)., 56: 958-965.

Elbein, A.D., Pan,Y.T., Pasttuszak,I. and Carroll, D.(2003). New insights on trehalose: a multifunctional molecule. G lycobiology J ournal,0 xford university press, 13: 17R-27R.

Fonagy, A. (2009). Insect timing (rhythms) from the point of view of neuroendocrine effector mechanism. Acta. Phytopathologica et. E ntomologica H ungarica., 44: 61-73.

Froy, O., Gotter, A. L., Casselman, A. L. and Reppert, S. M. (2003). Illuminating the circadian clock in monarch butterfly migration. Science, 300: 1303-1305.

Giebultowicz, J.M. (2001). Peripheral clocks and their role in circadian timing: insights from insects. Phil. Trans. R. Soc. Lond. B., 356: 1791-1799.

Gilby, A. R., Wyatt, S. S. and Wyatt, G. R. (1967). Trehalases from the cockroach, Blaberus discoidalis: activation, solubilization and properties of the muscle enzymes and some properties of the intestinal enzyme. Acta Biochim. Polon., 14: 83-100.

Goldsworthy,G. J. and Gade, G. (1983). The Chemistry of Hypertrehalosemic Factors. In: Downer, R. G H., and Laufer, H (ed.), Endocrinology of Insects, New York: Alan R. Liss. pp. 109-119

Goto, M., Li,Y.P, Kayaba, S., Outani, S. and Suzuki, K. (2001) Cold hardiness in summer and winter diapauses and postdiapause pupae of the cabbage armyworm, Mamestra brassicae L. under temperature acclimation. J ournal of Insect Physiol., 47: 709-714.

Hall, J. D. (2003). Genetics and Molecular Biology of Rhythms in Drosophila and other insects. Academic Press: Amesterdam. pp. 286

Han, R.D., Gan, Y. L., Kong, X. H. and Ge, F. (2008). Physiological and endocrine differences between diapauses and non diapausing larvae of the pine caterpillar D engrolimus tabulaeformis (Lepidoptera: Lasicampidae). Zoological Studies, 47: 96-102.

Hirayama, J. and Sassone-Corsi, P. (2009). Transcription control and the circadian clock. Encyclopedia of Neuroscience. pp 1071-1080.

Huang, J., Furusawa, T., Sadakane, K. and Sugimura, Y. (2006). Purification and properties of two soluble trehalases from embryonic larvae of the silkworm, B ombyx mori. J ournal of Insect Biotechnology and Sericology, 75: 1-8.

Ito,T. (1972). An approach to nutritional control mechanisms in silkworm, Bombyx mori. Israel J. Entomology, 7: 1-6.

Iwai, S., Fukui, Y., Fujiwara,Y. and Takeda, M. (2006). Structure and expressions of two circadian clock genes, period and timeless in the commercial silkmoth, Bombyx mori. J . Insect Physiol., 52: 625-637.

Iwami, M. (2000). Bombyxin: an insect brain peptide that belongs to the insulin family. Zool,Sci., 17: 1035-1044.

Jungreis, A. M. (1980). Hemolymph as a dynamic tissue. In: Locke, M., and Smith, D. S (ed.), Insect Biology in the Future. New York: Academic Press.pp 273-294

Kanamori, Y., Saito, A., Hagiwara-komoda, Y., Tanaka, D., Mitsumasu, K., Kikuta, S., Watanabe, M., Cornette, R. Kikawada, T. and Okuda, T. (2010). The trehalose transporter gene sequence is conserved in insects and encodes proteins with different kinetic properties involved in trehalose import into peripheral tissues. Insect Biochem and $\mathrm{M}$ ol Biol., 40: 30-37.

Khani, A., Moharamipour, S. and Barzegar, M. (2007). Cold tolerance and trehalose accumulation in overwintering larvae of the codling moth, Cydia pomonella (Lepidoptera: Tortricidae). European journal of E ntomology, 104: 385-392.

Kostal, V. and Shimada, K. (2001). Malfunction of circadian clock in the non- photoperiodic- diapauses mutants of the Drosophilid fly,Chymomyza costata. J . Insect Physiol., 47: 1269-1274.

Krishnaswami, S. (1986). New technology of silkworm rearing. Central Sericulture and Training Institute, Mysore, India.

Leevers, S. J. (2001). Growth control: invertebrate insulin surprises. Curr. Biol., 11: R 209- R 212.

Lokesh, G., Ananthanarayana, S.R. and Yoganandha murthy, V.N. (2012). Changes in the activity of digestive enzymes in respose to chemical mutagen diethyl sulfate in the silkworm Bombyx mori. L. (Lepedoptera: Bombycidae). Asian J. Applied Sci., 1-7.

Nagasawa, H., Kataoka, H. and Suzuki, A. (1990). Chemistry of Bombyx prothoracicotropic hormone and bombyxin. In: Ohnishi, E., and Ishizake, H (ed.), Molting and metamorphosis (pp 33-48), Berlin: Springler-Verlag. 
Naidoo, N., Song, S., Hunter-ensor, M. and Sehgal, A. (1999). A role for the proteosome in the light response of the timeless clock protein. Science, 285: 1737-1741.

Narayanaswamy, T. K. and Shankar, M. A. (2010). Impact of organic based nutrient management on the activity of trehalase and protease enzymes in the midgut extract of silkworm, Bombyx mori. L. M ysore. J . Agric. Sci., 44: 272-275.

Nath, B.S. (2000) Changes in carbohydrate metabolism in haemolymph and fatbody of the silkworm, Bombyx mori L., exposed to organophorous insecticides. Pestic. Biochem.Physiol., 68:127-137.

Nijhout, H.F. (1994). Insect hormones. Princeton: Princeton university press.

Oda, Y., Uejuma, M., Iwami, M. and Sakurai, S. (2000). Involvement iof adipokinetic hormone in the homeostatic control of haemolllymph trehalose concentration in larvae of Bombyx mori. Arch. Insect Biochem. Physiol., 45: 156165.

Orchard, I., Ramirez, J.M. and Lange, A.B. (1993). A multi functional role for octopamine in locust flight. Ann. Rev. Entomol., 38: 227-249.

Peschel, N., Chen, K. F., Szabo, G. and Sanewsky, R. (2009) Light dependent interactions between the Drosophila circadian clock factors cryptochrome, jetlag and timeless. Curr. Biol., 19: 241-247.

Roe, R. (1955). The determination of sugar in blood and spinal fluid with anthrone reagent. J ournal of Biological C hemistry, 20: 335-343.

Roeder, T. (1999). Octopamine in invertebrates. Prog. Neurobiol., 59: 533-561.

Rulifson, E.J., Kim, S.K. and Nusse, R. (2002). Ablation of insulin producing neurons in flies: growth and diabetic phenotypes. Science, 296: 1118-1120.

Sailaja, B. and Sivaprasad, S. (2010) a. Photoperiodic modulation of circadian rhythms in the silk gland protein profiles of Bombyx mori and its influence on the silk productivity and quality. J . Appl \& Nat. Science, 2: 48-56.

Sailaja, B. and Sivaprasad, S. (2010) b. Photoperiodic modulation of circadian protein rhythm in the silk gland of B ombyx mori during fourth instar development. The Bioscan, 5: $177-183$

Sailaja, B. and Sivaprasad, S. (2011). Photoperiod-induced clock shifting in the circadian protein and amino acid rhythm in the larval fat body of silkworm, Bombyx mori. J. Appl $\&$ Nat. Science, 3: 38-50.

Sailaja, B., Bhuvaneswari, E., Kavitha, S. and Sivaprasad, S. (2011). Photoperiod-induced clock shifting in the circadian protein and amino acid rhythm in the larval haemolymph of the silkworm, B ombyx mori. The Bioscan, 6: 355-363.

Saito, S. (1960). Trehalase of the silkworm, Bombyx mori: Purification and properties of the enzyme. J. Biochem., 48:101-109.

Satake, S., Masumura, M., Ishizaki, H., Nagata, K., Kataoka, H., Suzuki, A. and Mizoguchi, A. (1997). Bombyxin, an insulin-related peptide of insects, reduces the major storage carbohydrates in the silkworm Bombyx mori. Comp. Biochem. Physiol., 118B: 349-357.

Satake, S., Nagata, K., Kataoka, H. and Mizoguchi, A. (1999).
Bombyxin secretion in the adult silkmoth Bombyx mori: sex-specificity and its correlation with metabolism. I. Insect Physiol., 45: 939-945.

Saunders, D.S. (2002). Insect clocks, third edition (pp.560), Elsevier Science B.V.: Amsterdam.

Sehadova, H., Markova, E. P., Sehnal, F. and Takeda, M. (2004). Distribution of circadian clock related proteins in the cephalic nervous system of the silkworm, Bombyx mori. J. Biol. Rhythms, 19: 466-482.

Sharma,V. K. (2003). Adaptive significance of circadian clocks. Chronobiol. Int., 20: 901-919.

Shimizu, I. Kawai, Y., Tainguchi, M. and Aoki, S. (2001). Circadian Rhythm and cloning of the clock gene period in the honey bee Apiscerana japonica. Zoo. Sci., 18: 778789.

Shiva kumar, G. and Shamitha, G. (2011). Comparative studies of trehalase activity in the outdoor and total indoor reared tasar silkworm, Antheraea myl itta drury (Daba TV). Asian. J. Exp. Biol. Sci., 2: 265-269.

Sivaprasad, S. and Sailaja, B. (2011). Photoperiod-modulated instar-specific clock-shifting in the circadian protein and amino acid rhythms in the larval segmental muscle of B ombyx mori. J. Appl. \& Nat. Science, 3: 176-188.

Su, Z.H., Ikeda, M., Sato, Y. and Yamashita, O. (1993). Purification, C DNA cloning and nothern blot analysis of trehalase of pupal midgut of the silkworm, B ombyx mori. Biochem. Biophys. Acta., 1173: 217-224.

Sumida, M. and Yamashita, O. (1977). Trehalase transformation in silkworm midgut during metamorphosis. . . Comp. Physiol. B ., 115: 241-253.

Sutherland, E.W. (1972). Studies on the mechanism of hormone action. Science, 177: 401-408.

Syrova, Z., Dolezel, D., Sauman, I., Hodokova, M. (2003). Photoperiodic regulation of diapauses in liden bugs: are period and clock genes are involved. Cell.M ol.Lif. Sci., 60: 25102515.

Tang, B., Chen, X., Liu, Y., Tian, H., Liu, J., Hu, J., Xu, W. and Zhang, W. (2008). Charecterization and expression patterns of a membrane-bound trehalase from Spopter a exigua. BMC Molecular Biology., 9: 51.

Terra,W R. and Ferreira,C . (2005). Biochemistry of digestion. Comprehensive M olecular Insect Science, Elsevier, 4: 171-224.

Thompson, S.N. (2003). Trehalose- The insect blood sugar. Advances in Insect Physiology, 31: 206-261.

Wyatt, G.R. (1967). The biochemistry of sugars and polysaccharides in insects. Adv. Insect Physiol., 4: 287-360.

Yamaoka, K., Hoshino, M. and Hirai, T. (1971). Role of sensory hairs on the anal papillae in oviposition behaviour of B ombyx mori. J . Insect Physiol., 47: 2327-2336.

Yamashita, O. (1965). Carbohydrate metabolism during embryonic development of the silkworm, Bombyx mori.L. The J ournal of Sericultural Science of J apan, 34:1-8.

Yamashita, O. and Hasegawa, K. (1974). Mobilization of carbohydrates in tissues of female silkworms, Bombyx mori, during metamorphosis. J . Insect physiol., 20: 1749-1760.

Yanagawa, H. (1979). Effect of dietary levels of glucose on the metabolism of trehalose in the silkworm, B ombyx mori. The J ournal of Sericultural Science of J apan, 48:461-468. 